\title{
En alternativ ph.d.-afhandlings udfordring af den praktiske teologi
}

Udvidet review-artikel af Tenna Mose Rhigers ph.d.-afhandling Liturgiens Andedrat - Et liturgisk animationsteaterlaboratorium med fokus på udviklingen af en liturgisk teologisk og performativ tilgang til gudstjenestefejringen på 397 sider, indleveret til bedømmelse og forsvaret ved Graduate School, Arts, Aarhus Universitet, 2016.

\author{
Marianne Schleicher, Lektor ph.d. Aarhus Universitet \\ Vigdis Aune, Førsteamanuensis dr. art. Norges Teknisk- \\ naturvidenskabelige Universitet \\ Hans Raun Iversen, Lektor Københavns Universitet
}

\begin{abstract}
Tenna Mose Rhiger has written a PhD dissertation in which she has developed a new approach to the celebration of service in the Evangelical Lutheran Church in Denmark with the aim of furthering the intimate presence of pastors during service. The purpose of this extended review of Rhiger's dissertation is first to share the enthusiasm of the assessment committee for the project as well as its perspectives for Practical Theology and the celebration of service in the Evangelical Lutheran Church in Denmark. Secondly, the authors behind the review wish to advance some critical reflections on the formal requirements for similar experimental research projects in the future since this dissertation - as the pioneer work that it is - is likely to set the standards for "product dissertations" in the future.
\end{abstract}

Keywords: Practical Theology - Liturgy - Pastoral Performance - Practice as Research - Product Dissertation

Tenna Mose Rhiger har skrevet en ph.d.-afhandling, hvori hun udarbejder en ny tilgang til gudstjenestefejring med særligt henblik på at fremme præsters nærvær i den danske folkekirke. Formålet med denne anmeldelse af Rhigers ph.d.-afhandling er for det første at dele bedømmelsesudvalgets begejstring for projektet og dets perspektiver for den praktiske teologi og gudstjenestefejring i den danske folkekirke. For det andet vil bedømmelsesudvalget som forfattere bag denne anmeldelse anføre nogle kritiske overvejelser over, hvad der bør fordres af lignende eksperimenterende og eksperimentelle forskningsprojekter $\mathrm{i}$ fremtiden, eftersom afhandlingen, som det pionérarbejde den 
også er, meget vel kan komme til at sætte standarder for fremtidige "produktafhandlinger".

\section{Kropslige værktøjer som korrektiv til den praktiske teologi på universiteterne}

Afhandlingens sigte er at afdække et videnshul med hensyn til, hvad det performative betyder for gudstjenesten, og at udvikle "en værktøjskasse med kropslige værktøjer, der kan skabe mellemmenneskelig[t] nærvær, fokus og fællesskab i højmessens nuværende liturgi?” (8) Dette videnshul og det udviklingsprojekt, som forfatteren fremlægger, skal ses i forhold til den nyere, liturgisk-teologiske forskningshistorie i Norden, som forfatteren gennemgår på en måde, der synliggør både hendes positionering og inspiration (14-26).

I tråd med Bent Flemming Nielsens opfordring til at fokusere på kropslighed og mundtlighedssituationen i gudstjenesten som centrale for forkyndelsen og dens betydningsdannelse, skriver forfatteren sig ind i en aktuel dansk-nordisk forskning repræsenteret ved Kari Veiteberg, Lena Sjöstrand, Gunnfrid Ljornes Øierud, Kirstine Helboe Johansen og Jette Bendixen Rønkilde. Disse praktisk teologiske forskere fremhæver alle mellemmenneskelighed som definerende for gudstjenesten. Gudstjenesten ses her som "dybt afhængig af gudstjenestelederens performative egenskaber og af deltagernes faktiske deltagelse i begivenheden" (15). Afhandlingens originale bidrag består med afsæt $\mathrm{i}$ denne definition i at "udvikle en undervisningsmetode, som skal tjene til at kunne fremme det mellemmenneskelige nærvær i gudstjenestefejringen" (15) på baggrund af en øget performativ bevidsthed hos præster. Hermed udgør afhandlingen også et korrektiv til "den protestantiske insisteren på den teologisk reflekterende, semantiske og verbale betydningsdannelse" (16). Ligeledes i forhold til folkekirkelige initiativer uden for universiteterne er forfatteren nyskabende. Der er tidligere arrangeret liturgiske laboratorier, hvor teoretisk funderede diskussioner om "best practice" har domineret. Forfatterens kurser for fire præster i Løgumkloster, som udgør en væsentlig del af ph.d.-afhandlingens empiri, er imidlertid det første liturgiske laboratorium i akademisk regi og samtidigt det første, hvor laboratoriet lægger vægten på praktisk afprøvning (24-25). Afhandlingen er således et korrektiv til den praktiske teologi på universiteterne, idet der ikke er "nogen tradition for at afprøve teorier i praksis på de teologiske fakulteter, heller ikke i faget 'praktisk teologi"” (25). 
Handlinger og performative udtryk står centralt i ph.d.-afhandlingens undersøgelse. Undersøgelsen hviler på teserne, at gudstjenestefejringen er en performativ handling, der skaber en relation mellem aktør, iagttager og Gud; at viden er praksis; og "at undervisning med animationsfiguren som didaktisk redskab har potentialet til at kunne bygge bro mellem liturgien og den professionelle performative, liturgiske praksis” (10). På den baggrund stilles følgende spørgsmål, som undersøgelsen vil besvare:

Hvordan kan animationsfiguren hjælpe til større liturgisk kropsbevidsthed? Hvilke begrænsninger og benspænd skaber det, at introducere en helt ny praksis som vej til at forstå liturgien som performativ praksis? Og er det overhovedet muligt at oversætte redskaber tilegnet gennem dukkeførertræning til liturgiens ritualiserede sprog? (10-11).

En væsentlig styrke ved afhandlingen er dens bidrag til den praktisk teologiske forskning, idet den viser, hvordan elementer fra teaterverdenen, særligt brugen af animationsfigurer og performancelaboratorier, kan bringes i spil i forhold til den folkekirkelige gudstjenestes praksis og teologiske forståelse. Dermed peger afhandlingen frem mod udviklingen af humanistiske "produktafhandlinger". Afhandlingens grundtese, hvor præsten ses som gudstjenestens animator (og ikke blot dens kontrollerende leder eller helt modsat dens showmaster) har rige perspektiver både med hensyn til præstens opgave som liturgisk performer og med hensyn til den teologiske forståelse af gudstjenesten som aktivitetsform. Samtidigt bidrager afhandlingen med et bud på en ny model for forståelsen af forholdet mellem teori og praksis i den praktiske teologi - og i videre forstand i teologien, som gennem snart hundrede år har været spærret inde $\mathrm{i}$ et paradigme, hvor akademisk teologi helst skal være uden forbindelse til praksis, mens den kirkelige praksis risikerer at blive tilsvarende teoretisk underreflekteret. På disse punkter er afhandlingen klart på forkant i forhold til en udvikling, som presser sig på i den praktiske teologi i Danmark såvel som internationalt.

Et nødvendigvis teori- og metodepluralistisk forskningsdesign

Med henblik på at besvare problemformuleringen har Rhiger "afgrænset" sin empiri til at bestå af indledende interviews med fire deltagende præster, indledende observationer af deres gudstjenester, tre laboratorieseminarer, de fire præsters og Rhigers lærings- og reflek- 
sionsprocesser, præsternes øvelser i animation og liturgisk handlen, forfatterens afsluttende observation af de fire præsters gudstjeneste og endelig de fire præsters afsluttende evaluering af forløbet. Empirien fremlægges i kapitlerne 4-7 og i bilagsdelen i form af logbogsnotater, transskriptioner, fotos og videoer fordelt på 107 siders bilag og en ekstern harddisk.

Taget problemformuleringens interdisciplinære aspekter i betragtning sammensætter Rhiger klogt et flerfagligt og spændende teorigrundlag, der præsenteres i afhandlingens kapitel 2.

Afsnit 2.1 forholder sig til teorier hentet fra den kropsfunderede teaterpraksis, hvormed Rhiger reflekterer over, hvordan kroppens performative nærvær etableres. Rhiger slår fast, at gudstjenesten ikke kan sammenlignes med teater (18), men at teateret har en viden om, hvordan performative handlinger virker på tilskuere (11). Forfatteren syntetiserer den praksisbaserede tænkning hos Jerzy Grotowski, Eugenio Barba, Jacques Lecoq og Antonin Artaud og overfører deres refleksioner over forudsætningerne for "et større (scenisk) nærvær i nuet hos skuespilleren såvel som hos tilskueren ... til gudstjenestefejringen ... som et mellemmenneskeligt nærvær, der kan give bedre præmisser for forkyndelsen" (44). Idealet for performativ/ekstra-daglig handling er, at fokus rettes mod den kropslige handling i en sådan grad, at der bliver overensstemmelse mellem indre impuls og ydre reaktion. Den performende skal være som en passiv receptor, der modtager, er og udfører sin impuls. Forfatteren beskriver dette som en transcendering af tænkningens kontrol med kroppen, der medfører, "at en performance får sit organiske udtryk, som påvirker tilskuerne som samlet krop [..., hvilket] kan skabe et ekstraordinært nærvær" (46). Teknikken tænkes derfor som et arbejdsredskab for præster til at genopdage de inkulturerede handlinger, som de udfører under hver gudstjeneste og til samtidigt bedre at kunne improvisere, dvs. reagere på impulser i menighedsfællesskabet. Grotowski taler endda om 'den hellige skuespiller', der sætter sig selv til side for i stedet at tilbyde sit nærvær og åbenhed over for impulser fra salen, hvilket forfatteren sætter som model for præstens rolle (48-49). Trods overbevisende argumentation for, hvorfor teatervidenskabens praksisbaserede tænkning har noget at bidrage med til den praktiske teologi, skal det påpeges som en svaghed, at Rhiger i den sammenhæng ikke inddrager hverken kropsfænomenologien eller en teori om non-verbal kommunikation. F.eks. ville Julia Kristevas skelnen mellem sprogets semiotiske og symbolske modus ${ }^{1}$ kunne have forklaret, hvorfor den verbale kommunikation

1. Jf. Julia Kristevas doktorafhandling La Révolution du langage poétique fra 1974. Den foreligger delvist i engelsk oversættelse som "Revolution in Poetic Language", 
ikke kan etablere det nærvær, som den kropsfunderede teaterpraksis siges at formå, for således at tydeliggøre nødvendigheden af Rhigers kropsfunderede korrektiv.

Det ritualteoretiske begrebsapparat introduceres i afsnit 2.2 og består af religionsvidenskabelige og antropologiske bidrag fra Cathrine Bell, Caroline Humpfrey og James Laidlaw samt Anita Hammers teatervidenskabelige refleksioner over ritualer. Disse bidrag forstår ritualisering som handlinger, der konstituerer det hellige i opposition til det profane (49). I ritualer ritualiseres de deltagende kroppe gennem deres handlingsengagement, hvor en kropsliggjort føling med handlingers effekt $\mathrm{i}$ forhold til at skabe nærvær ideelt set vækkes. Hvor præster hidtil har fokuseret på teologiske tanker om handlingens betydning, fordrer Rhiger i højere grad nu præsters accept af gudstjenestens rituelle grundvilkår og hermed også af ritualiseringens præmisser (51). Rhiger tager imidlertid afstand fra Roy A. Rappaports kommunikative ritualteori og dennes tilhængere, som ifølge Rhiger hævder, at handlingens semantiske betydning på forhånd er givet. Denne udlægning af Rappaport virker misforstået, idet Rappaport netop understreger, at ritualets semantiske betydning ikke på forhånd må være helt fastlåst, da det vil stå i vejen for ritualets evne til at tilpasse sig forandring. Ritualets adaptive potentiale afhænger netop hos Rappaport af åbenheden over for individuelle fortolkninger af ritualet. I Ritual and Religion in the Making of Humanity taler Rappaport sågar om den effervescens, parallelbetydning og fællesskabsfølelse, som den kropsliggjorte deltagelse i ritualet etablerer uanset dets semantiske indhold. ${ }^{2}$ Her synes Rhiger at positionere sig op imod Rappaports ritualteori på baggrund af Nielsens og Johansens trods alt kortfattede gengivelse (Afhandlingen, 52) uden at fremlægge nuancerne fra Rappaports eget hovedværk. For at kompensere for det, som Rhiger vil undgå hos Rappaport, inddrager hun Hammers begrebspar prayer-play og belief-faith. Prayer forstås som ritualets rammesættende liturgi, mens play forstås som åbenhed over for impulser og variationer. Belief repræsenterer dogmatisk, institutionaliseret tro modsat faith, der er lokalt og privat forankret fortolkning af belief. Forfatteren fremhæver nødvendigheden af et dynamisk forhold mellem prayer, play, belief og faith som forudsætninger for, at en gudstjeneste kan blive vedkommende og dermed invitere til nærvær (53).

Det liturgisk-teologiske begrebsapparat, der præsenteres i afsnit 2.3, er hentet fra Gordon W. Lathrop, Geoffrey Wainwright og Alexander

The Portable Kristeva, red. Kelly Oliver (New York: Columbia University Press 2002), 27-92.

2. Roy A. Rappaport, Ritual and Religion in the Making of Humanity (Cambridge: Cambridge University Press 1999), 145-147. 
Schneemann, der i en økumenisk bestræbelse trods forskellige konfessionelle ståsteder søger tilbage til det oldkirkelige motto lex orandi, lex credendi (som man beder, sådan tror man) og oldkirkelige gudstjenestemønstre som handlinger mellem mennesker, der er konstituerende for troen, idet den gudstjenestelige handling kommer før den teologiske refleksion $(55-56,60)$. Vel sætter gudstjenesten en ramme om ritualet (se ovenfor om prayer), men verbale tolkninger skal også sikre, at "betydningsdannelsen falder indenfor den konkrete troskontekst" (57), hvilket kræver rum for gudstjenestens improvisatoriske mulighed, således at "de ritualiserede handlinger [kan] opleves som nye hver eneste gang, om end genkendelige, og dermed bevare det nærvær og fokus, som det kræver at opretholde en ekstradaglig handlingskarakter" (58). Afslutningsvis inddrages Helle Christiansen, der italesætter Kristi nærvær i gudstjenesten og idealet om et møde mellem evangelium og menighed, hvor den historiske distance mellem nutiden og antikken transcenderes. Dette kræver præstens nærvær og årvågenhed i forhold til impulser fra menigheden, hvortil Christiansen peger på mestring af åndedrættet som redskab (60-61). Hermed syntetiserer forfatteren den liturgiske teologi både bagud med sit udvalg af teaterantropologiske teorier og ritualteori og fremad mod sidste teoridel, der er hentet fra animationsteateret, hvor åndedrættet står centralt, jf. afhandlingens titel.

Afsnit 2.4 forklarer, hvordan animationsteater har relevans for det teoretiske begrebsapparat, og hvorfor animationsteateret kan tjene som didaktisk greb for præster til - ad kropslig vej - at nå frem til indsigter om selve den performative handling som betydningsskabende. Ifølge Rhiger er animationsprocessen nemlig et spørgsmål om, at "det dode objekt vakkes til live for et publikum af en forer, der lader sin energi smelte sammen med figurens" (62; Rhigers kursivering). Praktikere og teoretikere, der bidrager til afsnittet, tæller Michael Meschke, Eric Bass, medlemmer af Handspring Puppet Company, Penny Francis, Cariad Astels og Ida Hamre. Astels og Hamre understreger nærvær og kropsbevidsthed samt metarefleksion over de teaterantropologiske teorier som forudsætninger for at kunne animere en figur. Francis og Meschke italesætter, hvordan bevægelsen i dukketeater må komme før replikken, jf. Grotowski om nødvendigheden af åbenhed over for impulser udefra (64). At dukkeføreren må tilpasse sine bevægelser til dukken ligner ifølge forfatteren præstens behov for at akkulturere de inkulturerede handlinger i den ritualiserede krop, ikke kun for at gøre gudstjenesten ekstra-daglig, men også for "dannelsen og vedligeholdelsen af troen” (67). Dette kræver et ekstra nærvær og årvågenhed i forhold til at muliggøre figurens bevægelser som organiske (65). På den baggrund foreslår forfatteren, at animationsteateret kan tjene 
som didaktisk greb for præster til - ad kropslig vej - at nå frem til indsigter, der kendes fra teatervidenskab og den performative ritualteori om selve den performative handling som betydningsskabende.

En mangel i det ellers generelt flot sammentænkte teoriafsnit er en distinkt definition af det performative, der står yderst centralt, ja som sågar kan siges at være det begreb, der samler Rhigers mangfoldige teorivalg. Når formålet med afhandlingen endvidere er at "udvikle en undervisningsmetode, som skal tjene til at kunne fremme det mellemmenneskelige nærvær i gudstjenestefejringen” (15) på baggrund af en øget performativ bevidsthed hos præster, er det vigtigt, at ikke kun forfatteren, men også andre er helt sikre på, hvad man skal se efter, for at kunne genkende det performative.

Forfatteren skriver indledningsvist, at det er vanskeligt at definere det performative, men gør det alligevel som
en bevidst ændring af ens kommunikative, ritualiserede handlings kva- litative karakter - det nærvær handlingen udføres med, dens rettethed, den neutralitet kroppen pålægges for at lade tilskueren kunne danne sig sin egen mening om betydningsdannelsen. Det performative opstår på et præ-ekspressivt niveau, hvor det er den rene handling, den direkte relation mellem aktør og iagttager, og det nærvær dette kræver af begge parter, som skaber fællesskabet (7-8).

Endvidere skriver Rhiger, at gudstjenesten er en sådan performativ handling, der er dybt afhængig af bl.a. "gudstjenestelederens performative egenskaber" (15), hvorfor hun konstaterer et behov for at "øge den performative bevidsthed hos gudstjenestens deltagere - i første omgang præsten" (Ibid.).

At det performative kræver rettethed og plads til individuel fortolkning, er fint oplysende, men herefter savnes en definition. På den ene side er det performative kendetegnet ved at være en bevidst forandring af kvaliteten ved ens handling, og ved, at det især er præstens performative bevidsthed, der skal øges. På den anden side opstår det performative på et præekspressivt niveau med en kropslig neutralitet. Hvordan kan det performative være præekspressivt og kropsligt neutralt samtidig med, at det defineres som noget bevidst? Endvidere præsenteres nærvær på den ene side som et medium for den performative handling, mens nærvær på den anden side, afhandlingen igennem, præsenteres som resultatet af det performative. Om end inspirationen bag forfatterens indledningsvise definition ikke angives, er den formodentlig inspireret af teorierne, der gennemgås i kapitel 2. Her siges det s. 49, at "kroppen og kroppens performativitet i ritualet og i gudstjenesten er afgørende for evangeliets forkyndelse og menig- 
hedens fællesskab i gudstjenestefejringen”. Med andre ord er det nu kroppen, der er det primære medium for det performative. Med disse sparsomme og umiddelbart selvmodsigende informationer om det performative gives hverken den praktiske teolog eller den udøvende præst eksplicitte oplysninger om, hvori det performative består. Det undrer ligeledes, at den nok største performativitetstænker, Judith Butler, ikke er nævnt med et ord. Butler kunne oplagt have hjulpet med at præcisere det performatives kendetegn og endvidere bidraget med en spændende kompleksitet til Rhigers ideal om præsters akkulturering af inkulturerede handlinger. Endvidere ville Butler have tvunget Rhiger til at overveje, om ikke enhver handling, uanset om den er dagligdags eller ekstra-daglig, er performativ og konstituerende for den handlendes identitet? ${ }^{3}$

Helen Nicholsons dramapædagogiske teori om applied drama, der fik indflydelse på Rhigers dramapædagogiske refleksioner over, hvordan de fire præster skulle undervises i dukkeføring, præsenteres ikke i det indledende teorikapitel (kap. 2). Teorien om applied drama forklarer forudsætningerne for som leder med afsæt i kroppen at skabe ny indsigt hos andre og specifikt i forhold til afhandlingens problemstilling at fremme handlingsorienterede, kropslige praksisser blandt præster, så de kan bidrage til det mellemmenneskelige nærvær i gudstjenestefejringen (288-289). Forfatteren forklarer den sene teoripræsentation med, at hun først gjorde sig bekendt med Nicholsons teori efter at have erkendt, at forskningsprojektet havde ændret sig fra et laboratorium, hvor Rhiger skulle afprøve en animationsteaterbaseret undervisningsmetode til facilitering af en liturgisk teologisk og performativ tilgang til gudstjenestefejring hos de fire præster til en proces, hvor de fire præster i længere tid end forventet skulle undervises i dukkeføring, inden applikation heraf kunne sammentænkes med præsters liturgiske handlinger. Umiddelbart synes en dramapædagogisk teori relevant for forløbet, uanset hvilken vej det udviklede sig, og det ændrer ikke ved, at Nicholsons og andre dramapædagogiske teorier, som Rhiger burde kende fra sin uddannelsesmæssige baggrund på dramaturgi, skulle have været lagt frem indledningsvis for at forklare, hvad der har haft indflydelse på hendes - ofte intuitivt kloge - tilgang til empirien, inklusiv hendes korrektion af processen fra laboratorium til undervisning. Dispositionen kan dog - ikke legitimeres, men forklares ud fra Rhigers forveksling af proces med produkt, hvilket sandsynligvis skyldes hendes forståelse af Practice as Research-metoden.

3. Judith Butler præsenterer sin performativitetsteori med det dertilhørende begreb 'subversion' med relevans for akkulturering af kulturens rituelle og rituallignende handlinger i Gender Trouble (New York: Routledge 1990). 
Primær metode for ph.d.-projektet er Robin Nelsons Practice as Research, der præsenteres i kapitel 1. Rhiger gør her ikke rede for, på hvilke felter hun tilslutter sig denne tværfaglige forskningstradition, hvilket også kan forklare den svage redegørelse for forskningsdesign og metodens egnethed. Præsentationen er heller ikke udtømmende, men bygget således op, at forfatteren får præsenteret rationalet bag afhandlingens opbygning, herunder de meget procesbeskrivende kapitler 4, 5, 6 og 7, deres mange gentagelser og deres manglende karakter af traditionel akademisk analyse. Læseren får at vide, at man kan forvente en cyklisk form for forskning (35), "en form for 'liquidknowing" (36), der ikke vil bruge egentlig "reflection-in-action"” (36), da refleksion med dertilhørende teoriinddragelse og diskussion med teorien vil afbryde koncentrationen om praksis og de kropslige vidensgenererende processer, som deltagerne står $\mathrm{i}$, og som de derfor først skal indover bagefter. Hvorvidt forfatteren skelner mellem begreberne "refleksion-i-handling" og "refleksion-over-handling" står ikke klart. Rhiger har dog en klar bevidsthed om, at hendes afhandling på grund af metodevalg afviger fra traditionelle akademiske afhandlinger. Omvendt skriver hun, at afhandlingen afviger fra retningslinjer for Practice as Research-metoden ved alligevel at bringe et teorikapitel forud for undersøgelsen (37). At der skulle være tale om en afvigelse modsiges imidlertid af Nelson selv (Nelson 2013: 26; 37), der kræver særskilt indledningsvis præsentation af teori med henblik på dialog undervejs med praksis. Vigtigheden af dialog mellem praksis og teori argumenterer Rhiger dog klart for og følger således alligevel Nelsons anbefalinger $(35,39)$.

\section{Undersøgelsens svære proces og de betydningsfulde resultater}

I anden hoveddel (kap. 4-7) følger en "thick description" af laboratorie- og undervisningsprocessen, der i sin skriftlige form fremlægges som afhandlingens praksisprodukt suppleret af systematiske henvisninger til forskellige typer af skriftlige bilag samt foto- og filmmateriale. Her kan det diskuteres, hvorvidt det er legitimt at transformere Nelsons forestilling om et praktisk produkt til et tekstligt produkt uden uddybende argumentation herfor, jf. s. 24 inkl. fodnote 21, hvor forfatteren beskriver valget, uden dog at begrunde det. I denne "thick description" af laboratorie- og undervisningsprocessen er det endvidere meget krævende for læseren at følge forskningsprocessen, som den gengives i anden hoveddel (kap. 4-7) pga. dens parafraserende karakter og dens mange gentagelser. Denne fremlæggelse af 
en cyklisk forskningsproces er for så vidt konsistent med forfatterens opfattelse af metodologien i Nelsons Practice as Research, men ikke med bedømmelsesudvalgets opfattelse af selvsamme, jf. Nelson 2013, 26; 37. Hele anden hoveddel (kap. 4-7) får derfor bilagsagtig karakter, hvor en kondensering og selektering af materialet havde været $ø$ nskelig. Det lave taksonomiske niveau, den manglende selektion i dokumentationsmaterialet og den manglende opbygning af argumentation gennem opsummering af fund relateret til problemstilling og forskningsdesign i anden hoveddel (kap. 4-7) er således en svaghed ved afhandlingen, der ikke bør danne præcedens for kommende ph.d.-afhandlinger af lignende eksperimentel karakter. Samtidig kan man ikke benægte, at den omfattende dokumentation bevirker, at afhandlingens konklusioner - som de for alvor kommer til syne i tredje hoveddel (kap. 8-10), hvor anden hoveddels fremlagte empiri syntetiseres med teori, metodiske overvejelser og teologiske positioner fremstår ærligt kontekstafhængige og relaterede til sociale, praktiske, etiske og æstetiske aspekter ved den nære forskningskontekst og de fire deltagende præsters omliggende livskontekst. Uanset ovenstående kritik skal det derfor understreges, at mængden af dokumentation for så vidt også er en af afhandlingens styrker.

Tredje hoveddel (kap. 8-10) er til gengæld kendetegnet ved stringente analyser og diskussioner på et højt taksonomisk niveau. Kap. 8 evaluerer laboratorieseminarerne i lyset af et dramapædagogisk, et praktisk-teologisk og et liturgisk-teologisk synspunkt med vigtige kunstpædagogiske drøftelser af forholdet mellem laboratorium og undervisning og mellem kropslige, ikke-sproglige erfaringer og behovet for refleksioner over, hvordan mennesket lærer og erkender. Kap. 9 forklarer og vurderer i dialog med afhandlingens teorivalg laboratorieseminarernes liturgiske og praktisk teologiske implikationer for de fire deltagende præster. Ligeledes er det i dette kapitel, at forfatteren positionerer sig i forhold til praktisk teologi, dogmatik og liturgisk teologi. Beskrivelsen af disse fagområder er ikke udtømmende, men kun sjældent direkte unfair.

Kapitel 10, der udgør konklusionen, sammenfatter og besvarer problemformuleringens tre forskningsspørgsmål. På spørgsmålet om, hvordan animationsfiguren kan hjælpe til større liturgisk kropsbevidsthed, konkluderer Rhiger, at animationsfiguren kan fungere som "det fælles tredje, dvs. et fælles fokuspunkt for de tilstedeværende og en mulighed for at vurdere og diskutere, hvilke handlinger, der hjælper til at fremme figurens - og dermed også førerens - kropslige kommunikation" (350). Animationsfiguren skabte "en kropslig forståelse af det at kommunikere et budskab" (Ibid.) med udgangspunkt i "den enkelte deltagers udfordringer og udvikling” (Ibid.). På spørgsmålet 
om, hvilke begrænsninger og benspænd den introducerede praksis skabte for at forstå liturgien som performativ praksis, fremhæver Rhiger "diskrepanser mellem deltagernes og min forståelse af, hvad en laboratorieproces i en undervisnings- og forskningssammenhæng er" (351) og et "positivt frustrationsniveau" (Ibid.), der skyldtes bl.a. udfordringer for de fire præster i forhold til at "koble det talte sprog fra, så kroppen [fik] lov at træde frem som den primære kommunikator" (353). Med andre ord: "Ændringen i den liturgiske kropsbevidsthed er ikke noget, man kan læse sig eller diskutere sig frem til" (Ibid.). Disse ændringer er

subtile og svære at sætte fingeren på for den utrænede iagttager eller den vanemættede liturg. Det er åndedrættet, blikretningen, stemmeføringen, handlingens nærværskvalitet og ikke mindst hvordan man helt konkret, fysisk forvalter sakramenterne og Ordet (Ibid.).

Tredje og sidste forskningsspørgsmål vedrører oversættelsen af redskaber tilegnet gennem dukkeførertræning til liturgiens ritualiserede sprog og dens konsekvenser for præsternes liturgiske praksis og syn på egen rolle i gudstjenesten. Hertil konkluderer Rhiger, at præsterne som følge af dukkeførertræningen begyndte at tænke menigheden som langt mere medansvarlig for gudstjenesten end tidligere, og at det fordrede en større evne til at reagere på menighedens impulser (354). Den medførte også

[o]pdagelsen af, hvordan åndedrættet skabte både fællesskab, samhørighed og rum til at det enkelte medlem af menigheden kan være der med alt det, der er dem. Det bliver et liturgiens åndedrat, hvor man måske ikke trækker vejret i takt, men trækker vejret sammen” (355, Rhigers kursivering)

Den medførte, at "animationsfiguren havde været med til at højne [præsternes] fokus på det fælles tredje i gudstjenesten, på Gud” (357), fordi god animationspraksis er at minimere en opmærksomhed på dukkeføreren - eller i gudstjenestelig sammenhæng - på præsten.

\section{Perspektiv og eftertanke}

Ud over klare gevinster for den praktiske teologi og som et tilbud til mange præster om udvidelse af deres praktiske viden er Rhigers ph.d.-afhandling akademisk set interessant, hvad angår form. Af- 
handlingen peger frem mod nye genrer inden for ph.d.-afhandlinger og doktordisputatser, hvor selvstændige produkter ledsages af en akademisk tekst, sådan som det allerede kendes $\mathrm{i}$ ind- og udland i forbindelse med produktspecialer. En mulighed for, hvad man eksempelvis kunne kalde en produktafhandling, har Rhiger under den nuværende ph.d.-ordning ikke haft. Af den grund må det også regnes som en blandt afhandlingens mange styrker trods kritikken af anden hoveddel (kap. 4-7), at hun har udført et pionerarbejde, hvad angår form.

At introducere "produktafhandlingen" som en mulig genre til erhvervelse af de højeste akademiske grader vil ikke være fremmed for universitetsverdenen. Allerede i løbet af 1900-tallet opstod der et behov inden for flere fagområder for at retablere forbindelsen mellem teori og praksis, der syntes at være gået tabt i kølvandet på Oplysningstiden, hvor Immanuel Kants udskillelse af kunsten som område uden for fornuften førte til, at den praksisbaserede og ofte kropsligt eller mundtligt overleverede håndværksmæssige kunnen og kunst blev tilkendt en lavere status og blev holdt uden for udviklingen af de akademiske fag. Et vendepunkt for de forskellige universitetsfag i forhold til at anse praksis som kilde til forskning blev den pragmatiske filosofi. John Dewey understregede i How to Think fra 1910, at menneskelig erfaring altid er konkret, situeret og observationsbetinget som forudsætning for reflektorisk reaktion på rå data. Hans teori blev i 1960'erne afsæt for kunst- og designuddannelserne til at anvende praksisbaseret forskning med henblik på at udvikle reflekterede kunstnere på højt niveau. I 1970erne og -80erne skrev den pragmatiske filosof Donald Schön Theory in Practice; Increasing Professional Effectiveness (sammen med Chris Argyris) og The Reflective Practioner: How Professionals Think in Action om "viden-i-handling" og "reflekterende observation" med henblik på at udvikle en form for praksisepistemologi, der bl.a. inspirerede fag som pædagogik, sundhedspleje og arkitektur samt dramaturgi til at fokusere på deres respektive særegne, meningsbærende handlinger, vilkår og indarbejdede rutiner samt kropsliggjorte viden. ${ }^{4}$ Fælles for disse fag er, at de sigter mod at begrebsliggøre kvalitet og italesætte udfordringer og udviklingsmuligheder for en bedre faglig praksis. Seneste væsentlige bidrag er Practice as Research in the Arts fra 2013, hvor Robin Nelson forsvarer idéen om kreativ praksis i kunstfagene ved at præsentere en form for tavs, eksperimentel kundskab, der ikke kan genereres gennem traditionel akademisk forskning, ej heller gennem skriftlig argu-

4. Chris Argyris \& Donald Schön, Theory in Practice; Increasing Professional Effectiveness (San Fransisco: Jossey-Bass 1974); Donald Schön, The Reflective Practioner: How Professionals Think in Action (New York: Basic Books 1984). 
mentation. I stedet lægger han vægt på de fordele og udfordringer, der opstår i rummet mellem kreativ praksis og forskning. ${ }^{5}$

Formelle krav til en vellykket praksisbaseret forskning, som tilmed kan begrunde fremtidig inklusion af ikke-skriftlige dele i en ph.d.-afhandling eller sågar egentlige produktafhandlinger til erhvervelse af de højeste akademiske grader, bør være, at der skelnes mellem praksis og refleksion over praksis på mere gennemført vis, end det er tilfældet i Rhigers afhandling. Selve refleksionen og forskningsdesignet bør være styret af et fagligt begrebsapparat samt teori- og metodevalg, som på transparent vis skal begrunde fordele og udfordringer ved disse valg $\mathrm{i}$ forbindelse med både produktudvikling og analysen af det dokumenterede produkt. Endelig bør forfattere præcisere, hvordan praksis positionerer produktet i forhold til forskningshistorien. Med en sådan flerfoldig kontekstualisering af produktet, uanset om det er et interaktivt arbejde eller en metodedemonstration, en demonstrationsworkshop eller en lærerbog, sikres rammerne for at kunne supplere produktet med et skriftligt arbejde på højeste taksonomiske niveau. En forudsætning for disse overvejelser er imidlertid, at værtsuniversitetet anderkender praksisbaseret forskning og bl.a. tilbyder et ph.d.-program med særligt udviklede kursusdele og vejledninger, der er målrettet denne akademiske genre. Både ved Norges Teknisk-Naturvitenskapelige Universitet og Rhigers egen Graduate School, Arts, Aarhus Universitet - ikke uden relation til den situation, der opstod i forbindelse med bedømmelsen af Rhigers afhandling - er nye retningslinjer for udarbejdelse af ph.d.-afhandlinger undervejs. Trondheim synes at vælge en egentlig produktafhandling, hvor produkt og refleksion over praksis vægtes ligeligt, mens Aarhus i skrivende stund ser ud til at beslutte, at ph.d.-afhandlinger kan rumme ikke-skriftlige dele, der skal kontekstualiseres på lige fod med enhver anden empiri.

Rhiger havde ikke ovenstående retningslinjer at skrive sin ph.d.afhandling indenfor, og af den og andre grunde som anført ovenfor, vurderer vi samlet set, at denne på én gang eksperimenterende og eksperimentelle afhandling er nyskabende. Gennem sit tværfaglige forskningsdesign og det ihærdige arbejde med projektets gennemførelse, herunder Rhigers følsomhed over for æstetiske, etiske, teologiske og praktiske aspekter af problemstillingen og forskningsprocessen, leverer afhandlingen væsentlige og originale praktisk teologiske indsigter hånd $\mathrm{i}$ hånd med en berettiget, men generelt loyal kritik af faget, som forfatteren med denne afhandling ønsker at tilskynde til nye forsknings- og undervisningsmetoder.

5. For mere om praksisbaseret erkendelse, se tidsskriftserien Refleksion i praksis, udgivet af daværende Institut for Filosofi \& Idéhistorie, Aarhus Universitet (http:// ruml.au.dk/skriftserier/refleksionipraksis; set den 2. september 2016) 